\section{Self- and Cross-fertility in Recently Released Highbush Blueberry Cultivars}

\author{
Mark K. Ehlenfeldt ${ }^{1}$ \\ U.S. Department of Agriculture, Agricultural Research Service, Rutgers \\ Blueberry and Cranberry Research Center, 125A Lake Oswego Road, \\ Chatsworth, NJ 08019
}

\section{Additional index words. Vaccinium corymbosum, pollination}

\begin{abstract}
Self- and cross-fertility were evaluated in the highbush blueberry (Vaccinium corymbosum L.) cultivars Bluegold, Duke, Legacy, Nelson, Sierra, Sunrise, and Toro, all of which have been released since 1985 , by comparing them with 'Bluecrop' and 'Rubel', which were used as standards. Cross-pollination increased fruit set in all cultivars except 'Bluecrop', in which set was reduced $13 \%$. The average increase among recently released cultivars was $43 \%$. Cross-pollination also increased fruit weight for all cultivars except 'Rubel'. Average increase in fruit weight with cross-pollination of the recently released cultivars was $27 \%$. Fruit set and fruit weight measurements suggest that 'Duke', 'Legacy', and 'Nelson' would perform satisfactorily in solid stands, and that 'Sierra' and 'Toro' probably need cross-pollination for maximum yields.
\end{abstract}

When a new highbush blueberry cultivar is released, one of the concerns of growers is whether the cultivar can be planted in solid blocks. Solid-block planting results in a high proportion of self-pollinated flowers, and, for many blueberry cultivars, a reduced yield. The primary yield components in blueberry are total bud and flower number, percentage of fruit set (i.e., number of fruit) and fruit weight. A significant reduction in any of these factors reduces yields. Fruit set is depressed by selfpollination (El-Agamy et al., 1981; Meader and Darrow, 1947; Morrow, 1943; Rabaey and Luby, 1988). Krebs and Hancock (1988, 1991) suggested that this effect was due to inbreeding effects and embryo abortion.

Fruit weight is positively correlated with seed number in highbush blueberry (Brewer and Dobson, 1969; Eaton, 1967; Meader and Darrow, 1947; Moore et al., 1972). Eaton (1967) found an overall correlation of 0.59 between fruit size and seed number across a group of 13 highbush cultivars and selections. Similarly, Moore et al. (1972) found a correlation of 0.64 across 13 cultivars of highbush blueberry. Similar positive correlations have been documented between seed number and fruit size in V. angustifolium Ait. (Aalders and Hall, 1961; Jackson et al., 1972) based on measurements both within and among cultivars. Rabbiteye blueberries ( $V$. ashei Reade) are considered marginally self-fertile and are substantially less self-fruitful than highbush blueberries (El-Agamy et al., 1981; Garvey and Lyrene, 1987; Meader and Darrow, 1944).

\footnotetext{
Received for publication 14 Feb. 2000. Accepted for publication 12 July 2000 . The cost of publishing this paper was defrayed in part by the payment of page charges. Under postal regulations, this paper therefore must be hereby marked advertisement solely to indicate this fact.

'Research Geneticist.E-mail address:mehlenfeldt@ ars.usda.gov
}

Hence, effects of self-pollination in rabbiteye are generally more severe than those in highbush. In rabbiteye, correlations of seed number with fruit weight ranging from 0.38 to 0.80 have been reported (Ehlenfeldt and Hall, 1996; Kushima and Austin, 1979; Moore et al., 1972).

An additional concern related to the need for cross-pollination in highbush blueberry cultivars is how self-pollination will affect the time to fruit maturity. Fruit resulting from self-pollination ripen later because of their reduced seed numbers (Coville, 1921; Harrison et al., 1993; Meader and Darrow, 1947; Morrow, 1943)

This study evaluated the self- and crossfertility of seven recently released highbush blueberry cultivars to determine their relative pollination requirements. These cultivars were compared with 'Bluecrop' and 'Rubel', established commercial clones, which were used as standards.

\section{Materials and Methods}

In 1995 and 1996, 3-L pots containing 3 -year-old blueberry plants were brought into a screened, insect-free greenhouse in late January for pollination studies. The cultivars used (seven to nine plants each) were 'Bluegold', 'Duke', 'Legacy', 'Nelson', 'Sierra', 'Sunrise', and 'Toro', all of which have been released since 1985. 'Bluecrop' was included as a standard because it is the most widely grown and broadly adapted cultivar, and 'Rubel' because it has a reputation as being self-fruitful (Merrill, 1936; White and Clark, 1938).

Pollen was collected each day from one plant of each cultivar, which had been brought in earlier to serve as a pollen donor. Pollinations were made on nonemasculated, open flowers that were exhibiting stigmatic exudate. Closed flowers in the selected inflores- cences were removed, and pollen was liberally applied to the open flowers using a pencil tip. Selfs and outcrosses were randomly distributed among inflorescences on each plant, and all plants had both selfed and outcrossed inflorescences. For cross-pollination, all cultivars except 'Bluecrop' were pollinated with 'Bluecrop' pollen; 'Bluecrop' was pollinated with 'Rubel' pollen.

Inflorescences were tagged to indicate number and date of pollinations. In 1995, an effort was made to make a minimum of 100 pollinations per cross (Table 1). In 1995, this number was reached for all cultivars except 'Legacy', which had poor budset the previous year. In 1996, 'Nelson' had fewer than 100 pollinations for outcrosses, and 'Sunrise' had fewer than 100 pollinations in both categories. Fruit was allowed to ripen (at $\approx 24{ }^{\circ} \mathrm{C}$ ), and were collected three times a week until all had been harvested. Date of harvest was noted for all fruit in 1996 to allow calculation of ripening time (i.e., days between pollination and harvest). Seed was extracted by hand, and fruit weight and seed number were recorded for each individual fruit, except for the crosses of 'Duke' in 1995, in which the seed were accidentally bulked following extraction.

Means for fruit weight, seed per fruit, and ripening time in each year were evaluated for significant differences using $t$ tests with $\alpha=0.05$. Correlation analyses and $t$ tests were performed using MSTAT-C (Plant and Soil Science Dept., Michigan State Univ., East Lansing).

\section{Results and Discussion}

The expected trends of reduced fruit set and fruit weight, and longer ripening times following self-pollination were generally observed in the newer cultivars. However, response varied among cultivars, and some exceptions were observed (Table 1 ). These trends are best examined cultivar-by-cultivar.

'Bluecrop' had a high percentage of fruit set, and was notable among all cultivars in having a higher set for self- than for crosspollinations in both years (avg. $77 \%$ vs. $67 \%$ ). This observation should, however, be treated with some caution because 'Bluecrop' was outcrossed to 'Rubel', whereas the other cultivars were outcrossed to 'Bluecrop'. Crosspollination yielded significantly higher fruit weights than did selfing, averaging $25 \%$ higher across 2 years, and consistently increased seed number. Selfing significantly delayed ripening $(3 \mathrm{~d})$.

In 'Rubel', cross-pollination increased fruit set $29 \%$, but did not affect fruit weight. This supports, at least partially, the belief that 'Rubel' does not require cross-pollination. Despite the weight uniformity, the yield increase makes cross-pollination desirable, although the amount of increase may vary under field conditions. Cross-pollination increased seed per fruit significantly in 1995 , but not in 1996, and had no effect on ripening time.

The effect of cross-pollination in 1995 and 1996 varied most in 'Bluegold'. In 1995, selfing resulted in only $13 \%$ set vs. $58 \%$ for cross- 
Table 1. Number of pollinations, percentage of fruit set, fruit weight, seed number, and ripening time following self- and cross-pollination of nine highbush blueberry cultivars in 1995 and 1996.

\begin{tabular}{|c|c|c|c|c|c|c|c|c|c|c|c|c|c|c|c|}
\hline \multirow[b]{2}{*}{ Cultivar } & \multirow[b]{2}{*}{ Year } & \multicolumn{2}{|c|}{ No. of pollinations } & \multicolumn{3}{|c|}{ Fruit set $(\%)$} & \multicolumn{3}{|c|}{ Fruit wt $(\mathrm{g})$} & \multicolumn{3}{|c|}{ No. of seed/fruit } & \multicolumn{3}{|c|}{ Ripening interval (d) } \\
\hline & & $\begin{array}{l}\text { Self } \\
\end{array}$ & Cross & Self & Cross & $\%$ Inc. $^{2}$ & Self & Cross & \% Inc. & Self & Cross & $\%$ Inc. & Self & Cross & $\%$ Dec. \\
\hline \multirow[t]{3}{*}{ Bluecrop } & 1995 & 158 & 114 & 60 & 55 & & 1.69 & $2.04^{*}$ & & 5.5 & $36.0^{*}$ & & --- & --- & \\
\hline & 1996 & 206 & 205 & 94 & 78 & & 1.41 & $1.82^{*}$ & & 13.4 & $37.0^{*}$ & & 61 & $58^{*}$ & 4 \\
\hline & Avg & & & 77 & 67 & -13 & 1.55 & 1.93 & 25 & 9.5 & 36.5 & 284 & & & \\
\hline \multirow[t]{3}{*}{ Rubel } & 1995 & 114 & 114 & 39 & 62 & & 0.76 & $0.83^{\text {Ns }}$ & & 12.0 & $32.4^{*}$ & & --- & --- & \\
\hline & 1996 & 213 & 185 & 59 & 64 & & 0.97 & $0.93^{\mathrm{Ns}}$ & & 18.5 & $16.8^{\mathrm{NS}}$ & & 65 & $63^{\mathrm{NS}}$ & 3 \\
\hline & Avg & & & 49 & 63 & 29 & 0.87 & 0.85 & -2 & 15.3 & 24.7 & 61 & & & \\
\hline \multirow[t]{3}{*}{ Bluegold } & 1995 & 188 & 106 & 13 & 58 & & 0.98 & $1.05^{\mathrm{Ns}}$ & & 8.3 & $47.6^{*}$ & & --- & --- & \\
\hline & 1996 & 189 & 170 & 86 & 99 & & 1.32 & $1.56^{*}$ & & 13.0 & $36.0^{*}$ & & 69 & $61^{*}$ & 12 \\
\hline & Avg. & & & 50 & 79 & 58 & 1.15 & 1.31 & 14 & 10.7 & 41.8 & 291 & & & \\
\hline \multirow[t]{3}{*}{ Duke } & 1995 & 213 & 208 & $--^{y}$ & $---^{y}$ & $(4)^{y}$ & 1.51 & $1.51^{\mathrm{Ns}}$ & & 16.0 & $14.4^{\mathrm{NS}}$ & & --- & --- & \\
\hline & 1996 & 207 & 205 & 31 & 53 & 71 & 1.33 & $1.58^{*}$ & & 13.4 & $26.6^{*}$ & & 46 & $48^{\mathrm{Ns}}$ & -3 \\
\hline & Avg & & & --- & --- & & 1.42 & 1.55 & 9 & 14.7 & 20.5 & 39 & & & \\
\hline \multirow[t]{3}{*}{ Legacy } & 1995 & 19 & 32 & 74 & 100 & & 1.71 & $2.15^{\mathrm{vs}}$ & & 13.9 & $31.6^{*}$ & & --- & --- & \\
\hline & 1996 & 224 & 256 & 82 & 79 & & 1.47 & $1.62^{*}$ & & 13.0 & $28.6^{*}$ & & 65 & $62^{*}$ & 4 \\
\hline & Avg & & & 78 & 90 & 15 & 1.59 & 1.89 & 19 & 13.5 & 30.1 & 123 & & & \\
\hline \multirow[t]{3}{*}{ Nelson } & 1995 & 167 & 166 & 66 & 70 & & 1.59 & $1.82^{*}$ & & 11.5 & $17.3^{*}$ & & --- & --- & \\
\hline & 1996 & 111 & 64 & 62 & 67 & & 1.38 & $1.59^{*}$ & & 13.7 & $16.8^{\mathrm{NS}}$ & & 59 & $55^{*}$ & 7 \\
\hline & Avg & & & 64 & 69 & 8 & 1.49 & 1.71 & 15 & 12.6 & 17.1 & 36 & & & \\
\hline \multirow[t]{3}{*}{ Sierra } & 1995 & 116 & 114 & 58 & 78 & & 1.14 & $1.83^{*}$ & & 6.6 & $32.1^{*}$ & & --- & --- & \\
\hline & 1996 & 249 & 223 & 24 & 59 & & 1.05 & $1.55^{*}$ & & 3.1 & $26.1^{*}$ & & 63 & $53^{*}$ & 16 \\
\hline & Avg & & & 41 & 69 & 68 & 1.10 & 1.69 & 54 & 4.9 & 29.1 & 494 & & & \\
\hline \multirow[t]{3}{*}{ Sunrise } & 1995 & 211 & 114 & 64 & 91 & & 1.57 & $1.81^{*}$ & & 12.4 & $31.5^{*}$ & & --- & --- & \\
\hline & 1996 & 43 & 55 & 58 & 87 & & 1.04 & $1.63^{*}$ & & 7.4 & $22.6^{*}$ & & 52 & $51^{\mathrm{Ns}}$ & 3 \\
\hline & Avg & & & 61 & 89 & 46 & 1.31 & 1.72 & 31 & 9.9 & 27.1 & 174 & & & \\
\hline \multirow[t]{3}{*}{ Toro } & 1995 & 93 & 152 & 34 & 68 & & 1.52 & $2.55^{*}$ & & 4.8 & $38.6^{*}$ & & --- & --- & \\
\hline & 1996 & 232 & 285 & 71 & 71 & & 1.06 & $1.30^{\text {vs }}$ & & 4.9 & $35.7^{*}$ & & 68 & $61^{*}$ & 10 \\
\hline & Avg & & & 53 & 70 & 32 & 1.29 & 1.93 & 50 & 4.9 & 37.2 & 659 & & & \\
\hline \multicolumn{6}{|c|}{ Avg for new cultivars other than Bluecrop and Rubel } & 43 & & & 27 & & & 259 & & & 7 \\
\hline
\end{tabular}

${ }^{2}$ Percentage of increase for cross-pollination as compared with self-pollination.

${ }^{y}$ Count of numbers of fruit from these two sets of crosses was lost, but calculations based on seed number and seed per fruit suggest that set was not affected, and averaged $48 \%$ and $50 \%$, respectively, for self- vs. cross-pollination.

Ns, ${ }^{*}$ Nonsignificant or significant at $P \leq 0.05$, respectively.

pollination. In 1996, the same values were $86 \%$ and $99 \%$, respectively. Cross-pollination significantly increased fruit weight in 1996 and increased seed number in both years. Cross-pollination accelerated ripening by $8 \mathrm{~d}$; this was one of the largest changes observed in ripening time.

'Duke' was nearly as fertile with selfpollination as with cross-pollination. In 1995, counts of fruit set were lost, but calculations based on total seed number and seed per fruit suggest that set for self- and cross-pollinations were $48 \%$ and $50 \%$, respectively. Fruit weight and seed per fruit were also nearly identical in 1995. This agrees with field observations of 'Duke' that suggest that it is highly self-fertile in solid plantings. In 1996, however, cross-pollination increased fruit set $22 \%$ (31\% with self-pollination vs. $53 \%$ with cross-pollination) and also increased fruit weight and seed number. Only in 'Duke' was the mean ripening time for self-pollinated fruit slightly shorter ( $2 \mathrm{~d}$ ) than that for crosspollinated fruit; however, the difference was nonsignificant.

'Legacy' was notable for its high percentages of fruit set, both with self- and crosspollination, averaging $78 \%$ and $90 \%$, respectively, for 1995 and 1996. Cross-pollination increased fruit weight in 1996, but not in 1995 , and increased seed number per fruit in both years, and accelerated of ripening $(3 \mathrm{~d})$.

Cross-pollination had little effect on fruit set of 'Nelson', but increased fruit weight in both years. 'Nelson' was notable in having among the lowest seed numbers following cross-pollination, averaging 17.1 seed per fruit. Cross-pollination increased seed number in 1995, but not in 1996, and accelerated ripening by $4 \mathrm{~d}$. 'Bluecrop' is a parent of 'Nelson', and this factor may contribute to its low seed set with cross-pollination; a less closely related pollen source might have improved fruit set and fruit weight.

Cross-pollination affected all parameters in 'Sierra'. It increased fruit set $68 \%$ (41\% vs. $69 \%$ ) over 2 years. Fruit weight and seed per fruit were also increased significantly in both years. Seed number per fruit was very low following self-pollinations, suggesting low self-fruitfulness. This may be the result of a genetic background that includes both $V$. darrowi Camp and V. ashei (Brooks and Olmo, 1997). The large difference in seed set is also reflected in the significant $10-\mathrm{d}$ reduction in time of ripening following cross-pollination.

Cross-pollination increased fruit set in 'Sunrise' by $46 \%$, averaged across 2 years, increased fruit weight and seed number in both years (averaging $31 \%$ and $174 \%$, respectively), but did not significantly affect ripening time.

Like 'Sierra', 'Toro' appeared to have very low self-fertility. All parameters, and seed number in particular, were affected by crosspollination. Fruit weight was increased upon cross-pollination in 1995, and number of seed per fruit in both years. Ripening time was significantly hastened (7 d) in 1996.
Regressions of ripening time on seed number indicate whether seed number affects ripening time. These regressions were all highly significant (Table 2), with $r^{2}$ values ranging from 0.10 for selfs of 'Legacy' to 0.64 for outcrosses of 'Nelson'. Regression coefficients ranged from -0.2 to -0.4 for the majority of both the selfs and outcrosses. Regression coefficients (i.e., slopes) for the self-crosses were generally steeper than were those for outcrosses, with certain exceptions. Notably different were selfs of 'Rubel', 'Sierra', 'Sunrise', and 'Toro', all of which had coefficients of less than -0.7 . The lower coefficients in these particular selfs suggest that increases in seed number have a greater effect on ripening time. Note, however, that for three of these cultivars, low coefficients are associated with very low mean seed numbers. The mean seed numbers for selfs of 'Sierra', 'Sunrise', and 'Toro' (in 1996) were 3.1, 7.4, and 4.9, respectively. Apparently when seed set is very low, changes in seed number have a relatively large effect on ripening. Crosses with just slightly higher mean seed numbers had coefficients similar to those of most other crosses. 'Rubel' and 'Duke' were notable in that seed per fruit and ripening time were nearly identical in both the selfs and the outcrosses (Table 1).

The evaluations here provide data only on exclusively self- vs. cross-pollinated flowers. Under field conditions both self- and crosspollination are likely. Harrison et al. (1993) examined yield parameters from pollinations 
Table 2. Effects of self- vs. cross-pollination on coefficients of determination $\left(r^{2}\right)$ and regression coefficients (b) for: 1) fruit weight vs. seed number; and 2) ripening time vs. seed number for nine highbush blueberry cultivars in 1995 and 1996.

\begin{tabular}{|c|c|c|c|c|c|c|c|c|c|}
\hline \multirow[b]{3}{*}{ Cultivar } & \multirow[b]{3}{*}{ Year } & \multicolumn{4}{|c|}{ Fruit wt vs. seed no. } & \multicolumn{4}{|c|}{ Ripening time vs. seed no. } \\
\hline & & \multicolumn{2}{|c|}{ Self } & \multicolumn{2}{|c|}{ Cross } & \multicolumn{2}{|c|}{ Self } & \multicolumn{2}{|c|}{ Cross } \\
\hline & & $r^{2}$ & $\mathrm{~b}$ & $r^{2}$ & $\mathrm{~b}$ & $r^{2}$ & $\mathrm{~b}$ & $r^{2}$ & $\mathrm{~b}$ \\
\hline \multirow[t]{2}{*}{ Bluecrop } & 1995 & $0.08^{*}$ & 0.18 & $0.35^{* *}$ & 0.06 & --- & --- & --- & $\overline{---}$ \\
\hline & 1996 & $0.24^{* *}$ & 0.12 & $0.30^{* * *}$ & 0.05 & $0.14^{* * *}$ & -0.4 & $0.26^{* *}$ & -0.2 \\
\hline \multirow[t]{2}{*}{ Rubel } & 1995 & $0.55^{* *}$ & 0.05 & $0.14^{* *}$ & 0.04 & --- & --- & --- & --- \\
\hline & 1996 & $0.49^{* *}$ & 0.03 & $0.48^{* * *}$ & 0.04 & $0.49^{* *}$ & -1.1 & $0.12^{* *}$ & -0.4 \\
\hline \multirow[t]{2}{*}{ Bluegold } & 1995 & 0.05 & 0.25 & $0.24^{* * *}$ & 0.04 & --- & --- & --- & --- \\
\hline & 1996 & $0.48^{* *}$ & 0.06 & $0.27^{* * *}$ & 0.05 & $0.18^{* *}$ & -0.4 & $0.46^{* *}$ & -0.3 \\
\hline \multirow[t]{2}{*}{ Duke } & 1995 & $0.38^{* *}$ & 0.08 & $0.31^{* * *}$ & 0.09 & --- & --- & --- & --- \\
\hline & 1996 & $0.53^{* *}$ & 0.06 & $0.46^{* * *}$ & 0.05 & $0.28^{* * *}$ & -0.3 & $0.20^{* * *}$ & -0.4 \\
\hline \multirow[t]{2}{*}{ Legacy } & 1995 & 0.25 & 0.12 & 0.08 & 0.24 & --- & --- & --- & --- \\
\hline & 1996 & $0.46^{* *}$ & 0.07 & $0.13^{* *}$ & 0.07 & $0.10^{* *}$ & -0.3 & $0.14^{* * *}$ & -0.2 \\
\hline \multirow[t]{2}{*}{ Nelson } & 1995 & $0.36^{* * *}$ & 0.10 & $0.41^{* * *}$ & 0.11 & --- & --- & --- & --- \\
\hline & 1996 & $0.36^{* *}$ & 0.08 & 0.08 & 0.14 & $0.23^{* *}$ & -0.3 & $0.64^{* *}$ & -0.4 \\
\hline \multirow[t]{2}{*}{ Sierra } & 1995 & $0.18^{* *}$ & 0.17 & $0.25^{* *}$ & 0.07 & --- & --- & --- & --- \\
\hline & 1996 & $0.24^{* *}$ & 0.34 & $0.30^{* * *}$ & 0.06 & $0.18^{* * *}$ & -1.7 & $0.41^{* *}$ & -0.2 \\
\hline \multirow[t]{2}{*}{ Sunrise } & 1995 & $0.37^{* *}$ & 0.07 & $0.27^{* *}$ & 0.06 & --- & --- & --- & --- \\
\hline & 1996 & $0.53^{* *}$ & 0.09 & $0.55^{* *}$ & 0.04 & $0.41^{* * *}$ & -0.8 & $0.50^{\text {*** }}$ & -0.3 \\
\hline \multirow[t]{2}{*}{ Toro } & 1995 & $0.40^{\text {** }}$ & 0.24 & $0.41^{* *}$ & 0.05 & --- & --- & --- & --- \\
\hline & 1996 & $0.46^{* *}$ & 0.18 & $0.48^{* * *}$ & 0.04 & $0.29^{* *}$ & -2.1 & $0.18^{* *}$ & -0.2 \\
\hline
\end{tabular}

,*** Significant at $P \leq 0.01$ and 0.001 , respectively.

of half-high blueberry cultivars with varying ratios of self and outcross pollen. For most cultivars the relationship between the measured parameters and the percentage of outcross pollen was linear, with fruit set, fruit weight, and seed number decreasing with percentage of outcross pollen. In most cases, 50:50 mixes gave results, which, although lower than those of $100 \%$ outcross pollinations, would still be considered acceptable. Values for $100 \%$ self-pollination did not align with the trend of values from various pollen mixes, reflecting the severe effect of inbreeding on fertilization.

The results suggest which cultivars might be more productive in solid plantings, and which cultivars would benefit most from some degree of cross-pollination. Although several of the newer cultivars, notably 'Duke', 'Nelson', and 'Legacy', appear to have good levels of self-fertility, cross-pollination still appears desirable to optimize fruit set and fruit weight, and to hasten maturity. 'Duke', which has been widely planted is reasonably selffertile in solid plantings. The 1995 data support this, but the 1996 data demonstrate that 'Duke' will benefit from cross-pollination in some years. 'Legacy' and 'Nelson', neither of which have been widely planted, also appear to be promising for planting in solid blocks.
Brooks and Olmo. 1997. Register of fruit and nut varieties, 3rd ed. Amer. Soc. Hort. Sci. Press., Alexandria, Va.

Coville, F.V. 1921. Directions for blueberry culture. U.S. Dept. Agr. Bul. 974.

Eaton, G.W. 1967. The relationship between seed number and berry weight in open-pollinated highbush blueberries. HortScience 2:14-15.

Ehlenfeldt, M.K. and M.R. Hall. 1996. Metrical analysis of a putative source of semi-seedlessness in rabbiteye blueberry, Vaccinium ashei Reade. HortScience 31:272-274.

El-Agamy, S.Z.A., W.B. Sherman, and P.M. Lyrene. 1981. Fruit set and seed number from self- and cross-pollinated highbush $(4 \times)$ and rabbiteye $(6 \times)$ blueberries. J. Amer. Soc. Hort. Sci. 106:443-445.

Garvey, E.J. and P.M. Lyrene. 1987. Self-incompatibility in 19 native blueberry selections. J. Amer. Soc. Hort. Sci. 112:856-858.

Harrison, R.E., J.J. Luby, and P.D. Ascher. 1993. Pollen source affects yield components and reproductive fertility of four half-high blueberry cultivars. J. Amer. Soc. Hort. Sci. 119:84-89.

Jackson, L.P., L.E. Aalders, and I.V. Hall. 1972. Berry size and seed number in commercial lowbush blueberry fields of Nova Scotia. Naturaliste Can. 99:615-619.

Krebs, S.L. and J.F. Hancock. 1988. The consequences of inbreeding on fertility in Vaccinium corymbosum L. J. Amer. Soc. Hort. Sci. 113:914918.

Krebs, S.L. and J.F. Hancock. 1991. Embryonic genetic load in the highbush blueberry, Vaccinium corymbosum (Ericaceae). Amer. J. Bot. 78:1427-1437.

Kushima, T. and M.E. Austin. 1979. Seed number and size in rabbiteye blueberry fruit. HortScience 14:721-723.

Meader, E.M. and G.M. Darrow. 1944. Pollination of the rabbiteye blueberry and related species. Proc. Amer. Soc. Hort. Sci. 45:267-274.

Meader, E.M. and G.M. Darrow. 1947. Highbush blueberry pollination experiments. Proc. Amer. Soc. Hort. Sci. 49:196-204.

Merrill, T.A. 1936. Pollination of the highbush blueberry. Michigan Agr. Expt. Sta. Tech. Bul. No. 181.

Moore, J.N., B.D. Reynolds, and G.R. Brown. 1972. Effects of seed number, size, and development on fruit size of cultivated blueberries. HortScience 7:268-269.

Morrow, E.B. 1943. Some effects of cross-pollination versus self-pollination in the cultivated blueberry. Proc. Amer. Soc. Hort. Sci. 42:469-472.

Rabaey, A. and J. Luby. 1988. Fruit set in half-high blueberry genotypes following self- and crosspollination. Fruit Var. J. 42:126-129.

White, E. and J.H. Clark. 1938. Some results of selfpollination of the highbush blueberry at Whitesbog, N.J. Proc. Amer. Soc. Hort. Sci. 36:305-309. 